\title{
Generating and Assessing Consumer's Innovation Adoption through Consumer Innovativeness, Innovation Characteristics and Perceived Brand Innovativeness
}

\author{
Alev Kocak Alan ${ }^{1}$, Ebru Tumer Kabadayi ${ }^{1}$, Selen Bakis ${ }^{1}$, Yesim Can $^{1} \&$ Melih Can Sekerin ${ }^{1}$ \\ ${ }^{1}$ Faculty of Business Administration, Gebze Technical University, Turkey \\ Correspondence: Alev Kocak Alan, Faculty of Business Administration, Gebze Technical University, Turkey. \\ E-mail: akocak@gtu.edu.tr
}

Received: November 10, 2017

Accepted: November 25, 2017 Online Published: November 29, 2017

doi:10.5539/ijms.v9n6p68

URL: http://doi.org/10.5539/ijms.v9n6p68

\begin{abstract}
Concerning the digitalism, globalization and competition; offering innovative products or services starts to become a critical issue for banks. Banks adapt its technological infrastructure for mobile banking applications to serve in more efficient and valuable way to their existing and potential customers. Unlike with the western countries, mobile technologies usage in developing countries have skipped lots of steps and become so popular. So for, one of the emerging market was chosen for the data collection and data were collected via internet survey with 451 participants. The effects of innovation characteristics (compatibility, ease of use, perceived usefulness, observability, perceived risk), consumer innovativeness and consumer perceived brand innovativeness on consumer innovation adoption were investigated in a holistic model. The results suggested that innovation characteristics had the most impact on consumer innovation adoption. Among these characteristics, compatibility and observability were most influential factors. Consumer innovativeness also affected adoption of innovations. However, contrary to the expectations, consumer perceived brand innovativeness' effect on adoption was not supported. Future research directions and managerial implications were also given.
\end{abstract}

Keywords: mobile banking, innovation adoption, consumer innovativeness, innovation characteristics, brand innovativeness, user satisfaction

\section{Introduction}

In today's globalized world that competition exceeds the country borders, innovativeness is accepted as one of the most crucial assets for firms' market success instead of its monetary assets (Kaplan, 2009). Changing consumer wants and needs, the advancement of new technologies and hyper competition are compelling firms to be innovative in order to survive in the marketplace (Kaplan, 2009). Therefore, firms are required to develop new products/services in support of "innovativeness" to become competitive in this rapidly changing marketplace (Brexendorf et al., 2015).

For consumer side, innovation has bazillion benefits for them and their adoption of innovation starts with becoming aware of the innovation and ends up with being a regular user of the innovation which refers to the final stage; adoption (Kotler \& Keller, 2012). Unless consumer develops a positive or negative attitude toward innovation, he/she does not adopt or reject it (Rogers, 2003). Rejikumar \& Ravindran (2012) also have proved that consumer satisfaction emerges after the adoption of the technology. The innovation adoption process is affected by various factors such as consumer's perception of new product/service characteristics under the name of innovation characteristics (Greer \& Murtaza, 2003; Jansson, 2011; Park \& Chen, 2007; Rogers, 1983; Rogers, 2003; Tornatzky \& Klein, 1982) and adopter characteristics such as demographics, psychographics etc. (Arts et al., 2011, Im et al., 2003; Lassar et al., 2005; Zhou, 2012). According to Wang et al. (2008), an insight into the most significant innovation adoption factors enables firms to determine their target markets, position their new products more precisely, and improve the effectiveness of their communication strategies.

Aaker (2007) conveys that branded innovations may serve businesses by affecting consumer's perceptions with regard to firm innovativeness. As Brexendorf et al. (2015) have asserted, branding concept has not studied much in the innovation literature despite its' critical role. Shams et al. (2015) have developed a scale to fill in the gap in the innovation adoption literature, named consumer perceived brand innovativeness, but there is a lack of 
research which integrates this concept with the innovation adoption models. Hence, this research investigates if there is a positive effect of consumer perceived brand innovativeness on innovation adoption. This research also aims to reveal the effects of innovation characteristics; namely, perceived usefulness, ease of use, compatibility, observability and perceived risk on the consumers' adoption of innovations for mobile banking service in the emerging markets.

The banking sector, one of the major sectors affected by innovation adoption has a new concern of finding ways for improving their operations in the new business environment with regards to advancements in information communication technologies (ICT) (Campanella et al., 2015). Sharma et al. (2017) state that in order to compensate the increased expenditure of banks for implementing ICT in their products and services and get in return for these technology investments, banks are trying to attract customers and prospects by offering improved technology infused services to boost their usage of technology level. Tan \& Teo (2000) have stated that banking sector should make continuous innovations and keep up with customers' demands of convenient, dependable, and purposive services (Tan \& Teo, 2000). From this point of view, the internet is a new way of serving customers with mobile banking applications and internet banking. According to ING International Survey (2015), Turkey was the first country in Europe to use mobile payment via their mobile devices and Turkey had the highest rank among European users of mobile banking. Markets like Turkey were seen as a future "hotspot" for mobile banking as a developing country. Mobile banking adoption seems high in Turkey, however, there is still a chance to increase the adoption rate to ensure the diffusion of mobile banking across country. Besides, there are very few studies that focus on the constitution of mobile banking adoption in the developing nations like Turkey (Bidar et al., 2014; Gumussoy, 2016; Hajiyev \& Chang, 2017). The main objective of this research is to examine the main drivers of innovation adoption of mobile banking in emerging nations by offering a comprehensive framework. Adoption of mobile banking will be measured via satisfaction of users as it displays the positive attitude toward innovation and leads to adoption intention and behavior (Fishbein \& Ajzen, 1977). By studying users' satisfaction to understand their innovation adoption behavior differentiates this study from others measuring adoption with actual usage (adoption behavior) by simply asking yes/no question or adoption intention. As Gumussoy (2016) has stated, most of the literature has measured intention to use mobile banking including consumers that have never used mobile banking before. However, satisfaction shows that real users of mobile banking are pleased with mobile banking usage and they adopt it. There are very few studies (Al-Jabri \& Sohail, 2012) that have used satisfaction as a measure of adoption of innovation. Thus, this research intends to extend the measurement of innovation adoption via user satisfaction.

\section{Theoretical Model and Literature Review}

The research investigates the effects of innovation characteristics, consumer innovativeness, and consumer perceived brand innovativeness on innovation adoption. Innovation characteristics are composed of perceived usefulness, ease of use, compatibility, observability, and perceived risk. The research model is presented in Figure 1.

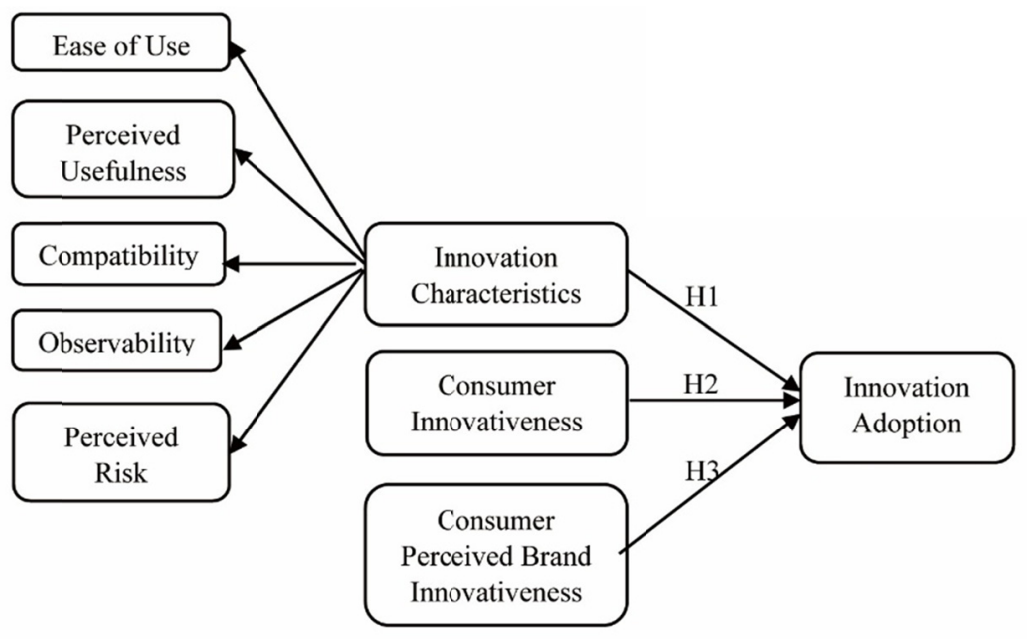

Figure 1. Conceptual model 


\subsection{The Adoption of Innovation}

Innovation is described by Rogers (2003) as follows: "an idea, practice or object that is perceived as new by an individual or other unit of adoption." (p. 12). In the literature, different theoretical models are used to explain consumers' innovation adoption. The Theory of DOI of Rogers (2003) is one of the most widespread ones that intends to explore the factors of individuals' innovation or new technology adoption. Rogers (2003) defines diffusion as the adoption of innovation within the current social system and as a result, the diffusion process ends up with the acceptance or penetration of new idea, behavior, or physical innovation. The adoption of innovation is also described by Rogers (2003) as consumers' decision of making use of innovation completely. According to Al-Jabri \& Sohail (2012), prior research that tries to understand individuals' adoption of mobile banking relies upon conceiving mobile banking as a technological innovation.

Another theoretical model explaining innovation adoption is Theory of Reasoned Action (TRA) of Fishbein \& Ajzen (1977), which has proposed the relationship between perception-attitude-intention-behavior. Consumer satisfaction of mobile banking displays the positive attitude and it will be utilized to measure innovation adoption; thinking that satisfied users of mobile banking should have adopted this innovation due to their positive attitude towards it. Satisfaction occurs after the trial of new product/service (Al-Jabri \& Sohail, 2012). Rejikumar \& Ravindran (2012) have stated that users' sense of satisfaction which takes places after the initial trial of product/service mostly determines the shift from the intention stage to adoption stage. Besides, satisfaction has higher face validity than other adoption scales such as implementation, usage, and utilization as Al-Jabri \& Sohail (2012) have stated. Moreover, if the users of a system state that they like that system, it means that the system is successful; and it is common to use satisfaction as a scale of success (Al-Jabri \& Sohail, 2012). Besides, satisfaction has been found to be an indispensable pre-requisite for consumers' continuance decision to use mobile banking (Gumussoy, 2016; Rejikumar \& Ravindran, 2012) and the behavioral intention to use mobile banking is affected positively by the attitude towards using mobile banking (Akturan \& Tezcan, 2012).

Rubera \& Kirca (2017) have stated that firms that follow a house-of-brands strategy which helps them communicate new products' advantages effectively can form deeper relationships with their customer as they know the specific needs of niche customers and develop new products according to this knowledge so, consumers can benefit from this as they easily perceive the added value of new offerings. However, firms try to satisfy a broad range of customers that have different needs and wants in corporate branding which they have to position their products accordingly as Rubera \& Kirca (2017) have implied. Their ability to assure consumers about the benefits of products is as important as customer satisfaction. Moreover, innovation means that firms invest in products that customers' demand, and it ensures consumers that firm is trying to meet their needs, thus it brings about customer satisfaction (Rubera \& Kirca, 2017).

\subsection{Innovation Characteristics and Innovation Adoption}

The innovation adoption generally relies on the analysis of consumer characteristics whose already having purchased the innovation rather than the ones that have not purchased yet; in order to separate adoption intention (Gupta \& Arora, 2017; Makanyeza, 2017; Zhou, 2012) and actual behavior (Greer \& Murtaza, 2003; Im et al., 2003; Szopiński, 2016).

Perceived ease of use is defined as the extent to which he/she believes that technology usage will be effortless (Davis, 1989). Perceived complexity is exactly the opposite of the perceived ease of use in TAM as Cheung et al. (2000) have stated. In this research, perceived ease of use is preferred rather than complexity. The impact of complexity on technology has been extensively studied. The complexity of services constantly has aroused as an obstacle to adoption of mobile payment (Mallat, 2007). According to Au \& Kauffman's (2008) study, some of the respondents have said that they would not have adopted mobile payments because of complexity. Users do not prefer mobile banking since it is a time-consuming action that requires a lot of effort (Al-Jabri \& Sohail, 2012). Studies indicate that perceived ease of use has a positive effect on continuance intention to use e-government (Hamid et al., 2016). Furthermore, perceived ease of use affects new technology adoption positively (He \& Veronesi, 2017) and has an influence in e-banking usage (Rodrigues et al., 2016). This study expects to see the positive effect of ease of use on mobile banking adoption.

Perceived usefulness characterizes "the extent to which a person believes that using particular technology will enhance his/her job performance" (Davis, 1989). Previous research finds out that perceived usefulness has a positive effect on continuance intention to use e-government (Hamid et al., 2016), intentions to buy halal-labelled products (Jamal \& Sharifuddin, 2015), mobile banking adoption (Al-Jabri \& Sohail, 2012), and attitude toward using smartwatches and adoption intention (Chuah et al., 2016). According to TAM, it is assumed that perceived usefulness and perceived ease of use are two key factors that determine the decision of consumer 
adoption of particular technology (Kang, 2011). So, these two factors are assumed to be belief dimensions that shape the (potential) users' attitude, which then determines intention to use and actual use (Chuah, 2016).

Compatibility means that the service is perceived by the user in accordance with their values, beliefs, habits, current and previous experiences (Rogers, 2003). With this approach, innovation can be in harmony with or incompatible with socio-cultural values and beliefs, with the individual's ideas and needs for innovation (Rogers, 2003). According to Tornatzky \& Klein (1982), a new approach is more easily adopted when it is compatible with the individual's value systems and job responsibilities. In addition, compatibility has been integrated into TAM model in the context of virtual merchandising (Chen et al., 2004), mobile payment (Chen, 2008) and mobile commerce (Wu \& Wang, 2005). In mobile banking, compatibility is also an important factor (Al-Jabri \& Sohail, 2012; Koenig-Lewis, 2010; Lin, 2011). Therefore, this study expects to reveal that the mobile banking service is well suited to the way consumers manage financial transactions, is compatible with consumers' work and lifestyles, and therefore consumers want to adopt mobile banking by forming the positive attitude.

Rogers (2003) defines observability as the degree that results of an innovation are visible to others. While results of some ideas are more visible to others, some of them are difficult to communicate and describe. High level of observability of an innovation helps it to be adopted more easily by the others (Rogers, 2003). Rogers (2003) has stated that technology is the designing of instruments to reduce the uncertainty in cause and effect relations in order to achieve the desired output. It has two components, hardware and software. Rogers (2003) proposes that an innovation that makes use of hardware, in which's physical substance can be observed easily, has a higher level of observability and the higher rate of adoption when it compared to an innovation that makes use of software, which has no physical existence. Moore \& Benbasat (1991) have simplified observability by dividing it and discussing as two different constructs, visibility and result demonstrability. Observability in the context of mobile banking is described as being able to connect to banking services in anywhere, at any time see the results and being able to communicate the benefits to others, by this way consumers observe mobile banking and get closer to adopt it (Al-Jabri \& Sohail, 2012). Thus, consumers observe mobile banking benefits and get closer to adopt it (Al-Jabri \& Sohail, 2012). Therefore, from that context, observability is expected to affect adoption of mobile banking users positively.

Perceived risk is a construct in consumer behavior that consumers are worried that undesired outcome will take place and result in a loss because of uncertainty or high potential of the undesired situation (Koenig-Lewis et al., 2010). As the theory of consumers' perceived risk suggests, consumers will perceive risk when there is an uncertainty or potential threat that will cause a loss for the consumer as a result of purchase (Dowling \& Staelin, 1994). It is commonly emphasized in the literature that perceived risk significantly effects innovation adoption (Akturan \& Tezcan, 2012; Arif et al., 2016; Bagadia \& Bansal, 2016; Brown et al., 2003; Koenig-Lewis et al., 2010; Makanyeza, 2017; Rogers, 1995). With these in mind, previous researches have shown that perceived risk can result in negative attitude for mobile banking adoption (Akturan \& Tezcan, 2012; Arif et al., 2016; Bagadia $\&$ Bansal, 2016). Consumers are worried about the possibility that their money or personal information may be transferred to other parties without their consent when using mobile banking (Hanafizadeh et al., 2014; Ramdhony \& Munien, 2013). Based on these findings, following hypothesis is established:

H1: Innovation characteristics (perceived usefulness, ease of use, compatibility, observability, and perceived risk) are positively related to the adoption mobile banking.

\subsection{Consumer Innovativeness and Innovation Adoption}

Rogers \& Shoemaker (1971) have described innovativeness as "the degree to which an individual is relatively earlier in adopting an innovation than other members of his system" (as cited in Midgley \& Dowling, 1978, p. 230). Innovative consumer has an outstanding role in the diffusion and adoption of innovations, several researches have pursued to determine the variables which are used to segment consumers into categories as innovators or late adopters (Goldsmith \& Hofacker, 1991; Hirshman, 1980; Im et al., 2003; Lassar et al., 2005; Truong, 2013). At first, new product/service is purchased and tried by few people and then more people decide to adopt the innovation; until nearly every consumer try or purchase it even once (Solomon et al., 2006). If the innovation is successful, it diffuses to the population. Adopters of any new innovation or idea are classified as innovators, early adopters, late majority and laggards with a normal distribution, as proposed by Rogers (Hong et al., 2017). Innovativeness concept is measured by being early to adopt innovation than others (Rogers, 1976) and has been a base for much research that employs the relative time of adoption methodology (Midgley \& Dowling, 1978).

Many indirect measurement techniques have been used by researchers to measure innovativeness concept empirically. Two main techniques are employed to measure innovativeness in the literature widely. First one is 
the variation of relative time of adoption and the second one is the ownership of newly launched products which can be also conceptualized as the cross-sectional method (Midgley \& Dowling, 1978). The first technique describes consumers as innovative, if they have bought a particular product in first $\mathrm{x}$ weeks or months etc. after it is launched in the market or they become the first x percent in the market to purchase (Midgley \& Dowling, 1978). The second technique works by measuring a number of products in the predetermined list which have been purchased by the consumer (Midgley \& Dowling, 1978). Midgley \& Dowling (1978) have stated that researchers that are measuring innovativeness with the cross-sectional technique are studying it with regard to a product category. These methods are used very commonly in the literature and all of them have its strengths and weaknesses (Goldsmith \& Hofacker, 1991). Midgley \& Dowling (1978) have suggested cross-sectional technique by emphasizing that it measures the construct deeply and more abstractly; which is related to individual's personality. Moreover, recent studies take innovativeness as a personality trait and highlight that consumer innovativeness remains as an important concept to understand the adoption of new products and predict consumer's innovative buying behavior ( $\mathrm{Li}$ et al., 2015).

Direct measurement techniques used by researchers are two-fold, general or innate innovativeness (e.g., Hirshman, 1980; Im et al., 2003; Lassar et al., 2005) and domain-specific innovativeness (e.g., Citrin et al., 2000; Goldsmith \& Hofacker, 1991; Truong, 2013) as mentioned by Citrin et al. (2000). Hirschman (1980) has described innate or general innovativeness as inherent novelty seeking and has stated that it is innate willingness to adopt new products. Reasonably, a consumer who possesses the willingness to adopt a new product also has the desire for novel experiences (Cowart et al., 2008). Goldsmith \& Hofacker (1991) have declared that compared to both "innate innovativeness" which is an abstract concept and "single product purchase" construct, domain-specific innovativeness is different from them with the reflection of specific consumer interest area. Domain-specific innovation refers to the inclination of consumers to get information about and adopt innovations that draw their attention or interest, and it provides a deep information of consumers' particular interest areas (Citrin et al, 2000). It refers to specific product category and its' use is popular for technological innovations (Truong, 2013). Citrin et al. (2000) have mentioned that domain-specific innovativeness measure has provided more beneficial consumer innovation adoption forecasts. Since mobile banking is seen as a technological innovation, domain-specific innovativeness with the technology interest area as a direct measurement technique is appropriate for this research. Prior research on consumer innovativeness have displayed that, it positively affected the new product/service adoption behavior (Arts et al., 2011; Im et al., 2003; Lassar et al., 2005), innovation adoption intention (Arts et al., 2011; Zhou, 2012), purchase intention (Persaud \& Schillo, 2017), continuance intention to use (Hong et al., 2017), and attitude towards innovation (Truong, 2013). Following hypothesis is established to test the effect of domain-specific consumer innovativeness on innovation adoption in the context of mobile banking:

$\mathrm{H} 2$ : Consumer innovativeness is positively related to the adoption mobile banking.

\subsection{Consumer Perceived Brand Innovativeness and Innovation Adoption}

Hirschman (1980) suggests that differences between new product adoption and diffusion may depend on consumers' perceptions about these products. Quellet (2006) is one of the first researchers that mentions consumer perceived brand innovativeness concept as "consumers' perceptions about a brand's tendency to engage in and support new ideas, novelty, experimentation, and creative processes" (as cited in Shams et al., 2015, p. 1593). According to Keller \& Aaker (1998), brand innovativeness is one of the most important constituents of brand images and competitive assets of the firm. Since brand innovativeness is the perception of innovativeness of a brand by consumers (Sanayei et al., 2013), their subjective assessments of brand innovativeness has a vital importance. Literature about innovation diffusion has not built consensus on the exact meaning of innovativeness and it is conceptualized from the consumer perspective as product/service innovativeness and firm innovativeness; without including brand-level perceptions of consumers (Shams et al., 2015). However, Shams et al. (2015) state that, conceptualization of innovativeness more widely at the brand-level should emphasize not only product characteristics and technology, but also the special meaning of brands' signal to the market when creating innovativeness image.

If consumers lack product performance related information meanwhile consumers are trying to decide on the adoption of a new product, they take extrinsic cues that go beyond the intrinsic product performance into consideration such as price and warranty information (Bearden \& Shrimp, 1982). The brand is an extrinsic factor and it has a strong effect on product/service adoption behavior. Consumers that are loyal to the brand adopt innovations earlier than new consumers do (Brexendorf et al., 2015). Shams et al. (2015) have asserted that in most of the times firm success depends on how consumers perceive their brand rather than new products' characteristics. Rather than product innovations, consumers seem to correlate perceived potential innovativeness 
with brand names. As reported by Shams et al. (2015), firms that want to be successful at positioning themselves as an innovative brand, at first they have to figure out how consumers perceive innovativeness at the brand level. As brands are introduced to the market under a parent brand name, consumers use their possessed information related to the brand when they decide upon innovativeness consciously or unconsciously (Shams et al., 2015).

Prior researches have supported that brand innovativeness concept has a positive effect on purchase intention (Hubert et al., 2017), willingness to pay (Hubert et al., 2017), brand commitment (Eisingerich \& Rubera, 2010), brand loyalty (Pappu \& Quester, 2016), emotional responses (Kaplan, 2009) and attitude toward brand (Pappu \& Quester, 2013; Sanayei et al., 2013). Eisingerich \& Rubera (2010) have studied brand innovativeness' effect on brand commitment when cultural dimensions moderates the relationship, and have found that brand innovativeness has a stronger effect on commitment in countries whose culture is individualistic, short-term oriented, and low on power distance. This study on the basis of Fishbein \& Ajzen (1977) expects that consumer perceived brand innovativeness will form positive attitude among consumers and then it will result in the adoption of innovation. Therefore, consumer perceived brand innovativeness is expected to affect the adoption of mobile banking positively.

H3: Consumer perceived brand innovativeness is positively related to the adoption mobile banking.

\section{Methodology}

\subsection{Data Collection and Sampling}

In order to test the proposed model and hypotheses, data were collected by using an online survey. The sample of this study was collected with convenient sampling and consisted of consumers that have used mobile banking in performing their financial transactions at least once in Turkey. Before the data collection, the pilot test was performed with 21 academicians who were using mobile banking in order to make sure that questions are clear. Some modifications were made after the pilot and the final questionnaire was comprised of 44 questions. After collecting the data through august, 451 surveys were obtained. Table 1 shows demographic characteristics of the participants.

Table 1. Demographic characteristics of the sample $(n=451)$

\begin{tabular}{lll}
\hline Characteristics & $\mathbf{N}$ & Valid \% \\
\hline Gender & 212 & 47 \\
Male & 239 & 53 \\
Female & 5 & \\
\hline Age & 213 & 1.1 \\
Younger than 20 & 148 & 47.2 \\
20-29 & 40 & 32.8 \\
$30-39$ & 43 & 8.9 \\
40-50 & & 9.5 \\
Older than 50 & 4 & \\
\hline Education & 4 & 0.9 \\
Primary school & 27 & 0.9 \\
Secondary school & 257 & 6 \\
College & 116 & 57 \\
University & 39 & 25.7 \\
Graduate School & & 8.6 \\
Doctorate & 26 & \\
\hline Income (Turkish Lira) & 205 & 5.8 \\
Less than 2.000 & 164 & 45.5 \\
2.001-5.000 & 52 & 36.4 \\
5.001-10.000 & & 11.5 \\
More than 10.000 & 25 & 5.5 \\
\hline Mobile Banking Usage Frequency & 18 & 4 \\
Not so much & 20 & 4.4 \\
Less than once in a month & 63 & 14 \\
Approximately once in a month & 138 & 30.6 \\
2-3 times in a month & 131 & 12.4 \\
4-5 times in a month & 56 & \\
Approximately once in a day & & \\
Few times a day & & \\
\hline & & \\
\hline
\end{tabular}




\subsection{Measures}

Constructs were measured with the five-point Likert scale indicating 1 for strongly disagree and 5 for strongly agree. The questionnaire consisted of five parts. In the first part, demographics were asked. In the second part, respondents answered questions regarding innovation characteristics thinking of their mobile banking usage experience. The next part included questions regarding brand innovativeness. Participants answered the questions by conceiving of their preferences of the most frequently used bank. In the next part, consumer innovativeness was assessed asking respondents to think of their personal characteristics. In the final part of the questionnaire, their attitude toward mobile banking was measured.

All of the scales used in this study were adapted from prior research and necessary changes were realized in the rewording of scales to mobile banking context. The innovation characteristics measure is a second-order construct and it is comprised of perceived usefulness, compatibility, ease of use, observability and perceived risk. In Table 2, measurement items of this research are presented.

Table 2. Factor loadings and reliability scores

\begin{tabular}{|c|c|c|c|c|c|c|}
\hline \multicolumn{3}{|c|}{ Construct } & $\begin{array}{l}\text { Standardized } \\
\text { loadings }\end{array}$ & $\begin{array}{l}\text { Cronbach's } \\
\text { Alpha }\end{array}$ & $\mathbf{C R}$ & AVE \\
\hline \multicolumn{3}{|c|}{ Innovation Characteristics } & & .824 & .817 & .597 \\
\hline \multicolumn{3}{|c|}{ Perceived Usefulness (adapted from Park \& Chen 2007) } & $.778 * *$ & .931 & .934 & .824 \\
\hline PU1 & $\begin{array}{l}\text { Using mobile banking would improve my job } \\
\text { performance. }\end{array}$ & $.934^{* *}$ & & & & \\
\hline PU2 & $\begin{array}{l}\text { Using mobile banking in my job would increase my } \\
\text { productivity. }\end{array}$ & $.904^{* *}$ & & & & \\
\hline PU3 & Using mobile banking would make it easier to do my job. & $.885^{* *}$ & & & & \\
\hline \multicolumn{3}{|c|}{ Compatibility (adapted from Al-Jabri \& Sohail 2012) } & $.940 * *$ & .852 & .853 & .743 \\
\hline $\mathrm{C} 1$ & Mobile banking is compatible with my lifestyle. & $.871^{* *}$ & & & & \\
\hline $\mathrm{C} 2$ & Using mobile banking fits into my working style. & $.853^{* *}$ & & & & \\
\hline \multicolumn{3}{|c|}{ Ease of Use (adapted from Wang et al. 2015) } & $.733 * *$ & .941 & .943 & .805 \\
\hline EOU1 & Learning to operate mobile banking is easy. & $.860^{* *}$ & & & & \\
\hline EOU2 & The use of mobile banking is clear and understandable. & $.903^{* *}$ & & & & \\
\hline EOU3 & It is easy to become skillful at using mobile banking. & $.912^{* *}$ & & & & \\
\hline EOU4 & Mobile banking is easy to use. & $.912^{* *}$ & & & & \\
\hline \multicolumn{3}{|c|}{ Perceived Risk (adapted from Al-Jabri \& Sohail 2012) } & $-.358 * *$ & .897 & .899 & .749 \\
\hline PR1 & Information about my transactions may be tampered by others. & $.821^{* *}$ & & & & \\
\hline PR2 & I fear that the PIN codes get lost \& end up in wrong hands. & $.887^{* *}$ & & & & \\
\hline PR3 & Information about my transactions may be known to others. & $.886^{* *}$ & & & & \\
\hline \multicolumn{3}{|c|}{ Observability (adapted from Greer \& Murtaza 2003) } & $.911 * *$ & .871 & .873 & .697 \\
\hline O1 & $\begin{array}{l}\text { I would have no difficulty telling others about the benefits of } \\
\text { using mobile banking. }\end{array}$ & $.789^{* *}$ & & & & \\
\hline $\mathrm{O} 2$ & The results of using mobile banking would be apparent to me. & $.853^{* *}$ & & & & \\
\hline $\mathrm{O} 3$ & $\begin{array}{l}\text { I would have difficulty explaining why using mobile banking } \\
\text { may or may not be beneficial. }{ }^{1}\end{array}$ & $.861^{* *}$ & & & & \\
\hline \multicolumn{3}{|c|}{$\begin{array}{l}\text { Consumer Perceived Brand Innovativeness } \\
\text { (adapted from Shams et al., 2015) }\end{array}$} & & .940 & .940 & .760 \\
\hline \multicolumn{3}{|c|}{$\begin{array}{l}\text { CPBI1 My mobile banking brand launches new services and creates } \\
\text { market trends all the time. }\end{array}$} & $.804 * *$ & & & \\
\hline CPBI2 & \multicolumn{2}{|l|}{$\begin{array}{l}\text { My mobile banking brand is an innovative brand when it comes } \\
\text { to mobile banking }\end{array}$} & $.871^{* *}$ & & & \\
\hline CPBI3 & \multicolumn{2}{|l|}{$\begin{array}{l}\text { My mobile banking brand makes new services with superior } \\
\text { design. }\end{array}$} & $.871^{* *}$ & & & \\
\hline CPBI4 & \multicolumn{2}{|l|}{$\begin{array}{l}\text { With regard to mobile banking, my mobile banking brand } \\
\text { constantly generates new ideas. }\end{array}$} & $.923 * *$ & & & \\
\hline CPBI5 & \multicolumn{2}{|l|}{$\begin{array}{l}\text { My mobile banking brand has changed the market with its } \\
\text { services. }\end{array}$} & $.885^{* *}$ & & & \\
\hline \multicolumn{3}{|c|}{ Consumer Innovativeness (adapted from Citrin et al., 2000) } & & .927 & .928 & .764 \\
\hline CI1 & \multicolumn{2}{|l|}{$\begin{array}{l}\text { In general, I am among the last in my circle of friends to visit } \\
\text { mobile bank's new website when it appears on the www. }{ }^{1}\end{array}$} & $.885^{* *}$ & & & \\
\hline CI2 & \multicolumn{2}{|l|}{$\begin{array}{l}\text { If I heard that a mobile bank's site was available on the web, I } \\
\text { would not be interested enough to shop from it. }{ }^{1}\end{array}$} & $.801 * *$ & & & \\
\hline CI3 & \multicolumn{2}{|l|}{$\begin{array}{l}\text { Compared to my friends, I seek out relatively little information } \\
\text { over the www. }\end{array}$} & $.919 * *$ & & & \\
\hline CI4 & \multicolumn{2}{|l|}{$\begin{array}{l}\text { I know about mobile bank's websites before most other people } \\
\text { in my circle do. }\end{array}$} & $.887 * *$ & & & \\
\hline
\end{tabular}




\begin{tabular}{|c|c|c|c|c|c|}
\hline \multicolumn{3}{|c|}{$\begin{array}{l}\text { Innovation adoption (adapted from Krishen et al., } 2016 \text { and Fatima \& } \\
\text { Razzaque, 2013) }\end{array}$} & \multirow[t]{5}{*}{.925} & \multirow[t]{5}{*}{.927} & \multirow[t]{5}{*}{.760} \\
\hline S1 & Overall, I am satisfied with mobile banking. & $.860 * *$ & & & \\
\hline S2 & $\begin{array}{l}\text { Overall, participation in mobile banking has } \\
\text { been an unsatisfactory experience. }{ }^{1}\end{array}$ & $.904 * *$ & & & \\
\hline S3 & $\begin{array}{l}\text { I think I did the right thing when I decided to use this mobile } \\
\text { banking for my banking needs. }\end{array}$ & $.877 * *$ & & & \\
\hline S4 & $\begin{array}{l}\text { Based on all my experiences with this mobile bank, I am very } \\
\text { satisfied with the services it provides. }\end{array}$ & $.846^{* *}$ & & & \\
\hline
\end{tabular}

Note 1. (Cross Coded).

Note 2. $\chi^{2}\left({ }_{339}\right)=564.595 ;{ }^{* *} \mathrm{p}<0.001 \mathrm{CMIN} / \mathrm{DF}=1.665 ; \mathrm{GFI}=.917 ; \mathrm{IFI}=.980 ; \mathrm{CFI}=.980 ; \mathrm{NFI}=.951$ and RMSEA $=.038$.

\subsection{Measure Assessments}

Factor loadings of each construct and the reliability estimates are displayed in Table 2. It is seen that the questionnaire is reliable since composite reliability (CR) scores range from 0.81 to 0.94 and there is high overall consistency among the items of all constructs since Cronbach's alpha estimates range from 0.82 to 0.94; which are greater than 0.70 (Hair et al., 2010). Besides, factor loadings of the constructs reveal that items in the constructs are large and significant, ranging from 0.35 to 0.94 ; which are greater than 0.33 . indicating a convergent validity (Fornell \& Larcker, 1981). The average variance extracted (AVE) values higher than 0.5 prove that there is a discriminant validity.

\section{Findings}

In order to test the conceptual model, AMOS 21 is used, which enables the analysis of multiple relationships simultaneously. Table 3 displays descriptive statistics and correlation estimates of the four construct used in the model. It can be concluded that all correlations are significant and are parallel with our expectations. Based on the Structural Equation Model (SEM), the conceptual model is determined and values are estimated based on the data set. The model fits the data perfectly well $\left(\chi^{2}=730.610(\mathrm{df}=342) ; \mathrm{CMIN} / \mathrm{DF}=2.136 ; \mathrm{GFI}=.893, \mathrm{IFI}=.966\right.$; $\mathrm{CFI}=.965 ; \mathrm{NFI}=.937$ and $\mathrm{RMSEA}=.050$ ).

Table 3. Descriptive statistics and correlations estimates

\begin{tabular}{lllllll}
\hline & Mean & SD & $\mathbf{1}$ & $\mathbf{2}$ & $\mathbf{3}$ & $\mathbf{4}$ \\
\hline 1. Innovation Characteristics & 4.044 & .450 & 1.00 & & & \\
2. Consumer Perceived Brand Innovativeness & 3.569 & .806 & $.318^{* *}$ & 1.00 & & \\
3. Consumer Innovativeness & 3.172 & .998 & $.343^{* *}$ & $.266^{* *}$ & .00 & \\
4. Innovation Adoption & 4.276 & .681 & $.696^{* *}$ & $.348^{* *}$ & $.370^{* *}$ & 1.00 \\
\hline
\end{tabular}
Note. ${ }^{* *} \mathrm{p}<0.001$.

Two out of three hypotheses are supported $\mathrm{n}$ this study. Table 4 indicates the structural parameter estimates for the hypotheses suggested. Regarding hypothesis testing, $\mathrm{H} 1$ which expects the positive relationship between innovation characteristics and innovation adoption is supported $\left(\beta=.079^{* * *}, \mathrm{t}=16.034, \mathrm{p}<0.01\right)$. Additionally, among three factors studied, the most influential factors that affect mobile banking adoption are innovation characteristics. Moreover, $\mathrm{H} 2$ which is proposing positive effect of consumer innovativeness on the innovation adoption is also supported $\left(\beta=.024^{*}, t=2.081, \mathrm{p}<0.05\right)$. It is the second most influential factor in innovation adoption. The last hypothesis $\mathrm{H} 3$ that expects positive relationship between consumer perceived brand innovativeness and innovation adoption is not supported $(\beta=.029, \mathrm{t}=1.226, \mathrm{p}>0.05)$.

Table 4. Structural parameter estimates

\begin{tabular}{lllll}
\hline Hypothesized path & & $\begin{array}{l}\text { Standardized } \\
\text { estimates }\end{array}$ & Results \\
\hline H1 & Innovativeness Characteristics $\rightarrow \quad$ Innovation Adoption & $.079^{* * *}$ & 16.034 \\
H2 Consumer Innovativeness $\rightarrow \quad$ Innovation Adoption & $.024^{*}$ & 2.081 & Supported \\
H3 Consumer Perceived Brand Innovativeness $\rightarrow$ Innovation Adoption & .029 & 1.226 & Not Supported \\
\hline
\end{tabular}

Note. ${ }^{*} \mathrm{p}<0.05 ;{ }^{* *} \mathrm{p}<0.01 ;{ }^{* * *} \mathrm{p}<0.001$. 


\section{Discussion}

Today's consumers are demanding more product/service variety and improvement, and differentiated products/services with affordable prices as Kaplan (2009) has stated. Firms are required to develop new products/services to become competitive in this rapidly changing marketplace (Brexendorf et al., 2015). Banking sector across the world is also affected by significant changes because of the main influence of advancements in information and communication technology, business intelligence, and risk management strategies (Campanella et al., 2015). Trying to adapt to this environment; banks seek for redefining relationships with their customers, opportunities which are provided by innovation processes, and harvesting sufficient income (Campanella et al., 2015).

Regarding second-order construct innovation characteristics, important findings were revealed. First, compatibility was found to have the most significant positive effect on mobile banking users' satisfaction. This finding is in line with Al-Jabri \& Sohail (2012) and Jansson (2011), and Tornatzky \& Klein (1982). Therefore, mobile banking seemed to be compatible with users' lifestyles, values, and working styles, as users were satisfied with it. Second most influential innovation factor was observability. Although some studies mentioned that observability in mobile banking context should have been irrelevant due to privacy issues (Tan \& Teo, 2000), this study included it. It was expected that observability was related to benefits of innovation's visibility and the communicability of its benefits to other consumers. Therefore, it was proved to impact satisfaction of mobile banking users' attitudes positively. Next factors were found to be perceived usefulness and ease of use, which were also consistent with the previous research (Bidar et al., 2014; Chuah, 2016). This finding revealed that users adopted mobile banking and became satisfied with it when mobile banking service technology was perceived as more useful than traditional banking services and the usage of this service was easy. The last impacting factor among innovation characteristics was perceived risk. This finding was also in line with the previous studies that found the negative impact of it (Laforet \& Li, 2005; Makanyeza, 2017; Tan \& Teo, 2000). Since this study included only users of mobile banking, perceived risk was not an important barrier to adoption, however, its' effect was significant.

In this study, consumer innovativeness was found to be the second most important factor to adopt innovations. Prior research was also in line with this finding that proved the positive relationship between consumer innovativeness and innovation adoption (Arts et al., 2011; Im et al., 2003; Lassar et al., 2005; Truong, 2013; Zhou, 2012). A study by Aldás-Manzano et al. (2009) found that consumer innovativeness of internet banking user directly increased the likelihood of becoming a heavier user of the internet banking, and reduced user's risk perception of this channel. Consumers adopted mobile banking more easily if they had possessed the innovative personal characteristic (Aldás-Manzano et al., 2009). In addition, Truong (2013) showed that culture had the mediator role between consumer innovativeness and perceived novelty, perceived value, perceived risk of technological innovation. Unlike with the western countries, mobile technologies usage in developing countries have skipped lots of steps and become so popular. Developing countries are likely to be more oriented towards new mobile services (Barnes \& Corbitt, 2003). Developing countries like Saudi Arabia, China and Turkey have also cought up technological advancements, since the internet have affected every countries and changed the way all business sectors perform. As ING International (2015) mentions, Turkey seems to adopt mobile banking quite well. This research's findings have also claimed that Turkish consumers find mobile banking beneficial, easy to use, worthy of recommendation, not so much risky and compatible with their lifestyles and values. The brand has a critical role in the adoption of innovations as they provide strategic focus and direction and support the launch and adoption of innovations (Brexendorf et al., 2015). Brand and innovation are interrelated, brands assure consumers about product/service, decrease the risk of satisfying consumers' product expectations. However, the expected positive relationship between consumer perceived brand innovativeness and innovation adoption was not supported. The reason behind not supporting H2 may be related to the dependent variable of the study, attitude towards mobile banking as an innovation. Sanayei et al. (2013) found that perception of the brand innovativeness affects attitude towards brand positively. However, this study had examined consumers' attitude toward product/service itself, not the brand. Innovation helps firms to build their offerings' reputation (Aaker, 2007), however, it may not affect the attitude toward their product/service's adoption. This result undoubtedly deserves more attention. Thus, other reason behind this finding might be related to cultural differences. The study by Eisingerich \& Rubera (2010) showed that culture took a mediator role in the relationship between brand innovativeness and brand commitment. It was empirically demonstrated that brand innovativeness had a greater effect on brand commitment in cultures that were the individualist, short-term oriented, and low on power distance (i.e., the United Kingdom) but the lower effect in cultures that were collectivist, long-term oriented, and high on power distance (i.e., China). Since Turkey is a country that has a collectivist culture and high power 
distance, it can be suggested that Turkish culture might be one of the reasons that the hypothesis regarding the relationship between consumer perceived brand innovativeness and adoption is not supported (Hofstede, 1983). Eisingerich \& Rubera's (2010) research might provide insights into the relationship between consumer perceived brand innovativeness and innovation adoption where similar moderator effect of culture might be found. Thus, integrating brand innovativeness into innovation adoption models will further the information regarding the factors that affect innovation adoption.

This study has several implications for managers. When developing new product/service, firms should take consumer perceptions into consideration since their attitude, intention, and behavior are in the same direction with them and they are very hard to influence. While firms are developing new products/services, they ensure that products/services are suitable for the way consumers perform their financial transactions. Insight into which product/service characteristics provide the strongest impact on mobile banking help managers to increase the diffusion of mobile banking usage among their all customers in a bank including traditional banking services and prospects. Consumers' values and lifestyles should also be acknowledged before new service development. Especially, mobile banking applications should be redesigned according to consumers' lifestyle, working style, and values. Also, benefits of mobile banking compared to traditional banking services should be emphasized in banks' advertisement campaigns. Besides, which benefits will mobile banking bring to consumers' lives, how easy to use this new service and how useful it is should be communicated by banks clearly via mass and personal marketing communications strategies. Besides, security risks and privacy issues that consumers might hold should also be eliminated with marketing communications of banks. By this way, consumers will be encouraged for the first trial of the service. If they hold positive attitudes towards them after the initial use, the adoption of innovation will be realized. Consumer innovativeness' positive effect on the adoption of mobile banking presents another crucial information since marketers can benefit from this information when positioning their new products/services in the market accordingly.

The main limitation of this study is related to sampling technique and generalizability of the research. Applying convenience sampling technique may not reflect the overall consumers' behavior for the entire country. Second, since the research is performed in Turkey and in the Turkish language, the implications of the study can be different for other cultures as it is mentioned earlier that culture can take a mediator role between brand innovativeness to brand commitment (Eisingerich \& Rubera, 2010). Future innovation adoption research may include culture as a mediator variable. Furthermore, future studies may study consumer perceived brand innovativeness construct in brand-related conceptual models, as brand related perceptions affect brand related attitudes.

\section{Conclusion}

This study tried to develop a conceptual model to explain factors influencing mobile banking users' adoption of this innovation in a holistic view. Not only innovation characteristics of mobile banking but also brand-related consumer perceptions and consumers' characteristics of being innovative were evaluated in this model. This research revealed that the most important factor that affects mobile banking adoption were innovation characteristics which were comprised of compatibility, observability, ease of use, perceived usefulness and perceived risk. Among these innovation characteristics, compatibility was found to be the most influential factor in mobile banking adoption which was followed by observability, perceived usefulness, ease of use and perceived risk. Studying satisfaction of mobile banking users to measure innovation adoption is the most important contribution of this study that differentiates itself from others. Thus, the measurement of user satisfaction in innovation adoption studies should be extended in the literature.

\section{References}

Aaker, D. (2007). Innovation: Brand it or lose it. California Management Review, 50(1), 8-24. https://doi.org/10.2307/41166414

Akturan, U., \& Tezcan, N. (2012). Mobile banking adoption of the youth market: perceptions and intentions. Marketing Intelligence \& Planning, 30(4), 444-459. https://doi.org/10.1108/02634501211231928

Al-Jabri, I. M., \& Sohail, M. S. (2012). Mobile banking adoption: Application of diffusion of innovation theory. Journal of Electronic Commerce Research, 13(4), 379-391.

Aldás-Manzano, J., Lassala-Navarré, C., Ruiz-Mafé, C., \& Sanz-Blas, S. (2009). The role of consumer innovativeness and perceived risk in online banking usage. International Journal of Bank Marketing, 27(1), 53-75. https://doi.org/10.1108/02652320910928245

Arif, I., Afshan, S., \& Sharif, A. (2016). Resistance to adopt mobile banking in a developing country: evidence 
from modified TAM model. Journal of Finance and Economics Research, 1(1), 23-38.

Arts, J. W., Frambach, R. T., \& Bijmolt, T. H. (2011). Generalizations on consumer innovation adoption: A meta-analysis on drivers of intention and behavior. International Journal of Research in Marketing, 28(2), 134-144. https://doi.org/10.1016/j.ijresmar.2010.11.002

$\mathrm{Au}, \mathrm{Y}$. A., \& Kauffman, R. J. (2008). The economics of mobile payments: Understanding stakeholder issues for an emerging financial technology application. Electronic Commerce Research and Applications, 7(2), 141-164. https://doi.org/10.1016/j.elerap.2006.12.004

Bagadia, P. \& Bansal, A. (2016). Risk perception and adoption of mobile banking services: a review. IUP Journal of Information Technology, 12(1), 52-71.

Barnes, S. J., \& Corbitt, B. (2003). Mobile banking: concept and potential. International Journal of Mobile Communications, 1(3), 273-288, https://doi.org/10.1504/IJMC.2003.003494

Brexendorf, T. O., Bayus, B., \& Keller, K. L. (2015). Understanding the interplay between brand and innovation management: findings and future research directions. Journal of the Academy of Marketing Science, 43(5), 548-557, https://doi.org/10.1007/s11747-015-0445-6

Bearden, W. O., \& Shimp, T. A. (1982). The use of extrinsic cues to facilitate product adoption. Journal of Marketing Research, 229-239. https://doi.org/0.2307/3151623

Bidar, R., Fard, M. B., Salman, Y. B., Tunga, M. A., \& Cheng, H. I. (2014). Factors affecting the adoption of mobile banking: sample of Turkey. In Advanced Communication Technology (ICACT), 2014 16th International Conference on (pp. 1278-1282). IEEE. https://doi.org/10.1109/ICACT.2014.6779165

Brown, I., Cajee, Z., Davies, D., \& Stroebel, S. (2003). Cell phone banking: predictors of adoption in South Africa-an exploratory study. International Journal of Information Management, 23(5), 381-394. https://doi.org/10.1016/S0268-4012(03)00065-3

Campanella, F., Della Peruta, M. R., \& Del Giudice, M. (2015). The Effects of Technological Innovation on the Banking Sector. Journal of the Knowledge Economy, 8(1), 356-368. https://doi.org/10.1007/s13132-015-0326-8

Cheung, W., Chang, M. K., \& Lai, V. S. (2000). Prediction of internet and world wide web usage at work: a test of an extended Triandis model. Decision Support Systems, 30(1), 83-100. https://doi.org/10.1016/S0167-9236(00)00125-1

Chen, L., Gillenson, M., \& Sherrell, D. (2004). Consumer acceptance of virtual stores: A theoretical model and critical success factors for virtual stores. ACM SIGMIS Database, 35(2), 8-31. https://doi.org/10.1145/1007965.1007968

Chen, L. D. (2008). A model of consumer acceptance of mobile payment. International Journal of Mobile Communications, 6(1), 32-52. https://doi.org/10.1504/IJMC.2008.015997

Chuah, S. H., Rauschnabel, P. A., Krey, N., Nguyen, B., Ramayah, T., \& Lade, S. (2016) Wearable technologies: The role of usefulness and visibility in smartwatch adoption. Computers in Human Behavior, 65, 276-284. http://dx.doi.org/10.1016/j.chb.2016.07.047

Citrin, A. V., Sprott, D. E., Silverman, S. N., \& Stem Jr, D. E. (2000). Adoption of Internet shopping: the role of consumer innovativeness. Industrial Management \& Data Systems, 100(7), 294-300. https://doi.org/10.1108/02635570010304806

Cowart, K. O., Fox, G. L., \& Wilson, A. E. (2008). A structural look at consumer innovativeness and self-congruence in new product purchases. Psychology \& Marketing, 25(12), 1111-1130. https://doi.org/10.1002/mar.20256

Davis, F. D. (1989). Perceived Usefulness, Perceived Ease of Use, and User Acceptance of Information Technology. MIS Quarterly, 13(3), 319-340. https://doi.org/10.2307/249008

Dowling, G. R., \& Staelin, R. A. (1994). Model of perceived risk and intended risk-handling activity, Journal of Consumer Research, 21(1), 119-134. https://doi.org/10.1086/209386

Eisingerich, A. B., \& Rubera, G. (2010). Drivers of brand commitment: A cross-national investigation. Journal of International Marketing, 18(2), 64-79. https://doi.org/10.1509/jimk.18.2.64

Fishbein, M., \& Ajzen, I. (1977). Belief, attitude, intention, and behavior: An introduction to theory and research. 
Fornell, C., \& Larcker, D. F. (1981). Structural equation models with unobservable variables and measurement error: Algebra and statistics. Journal of Marketing Research, 382-388. https://doi.org/10.2307/3150980

Goldsmith, R. E., \& Hofacker, C. F. (1991). Measuring consumer innovativeness. Journal of the Academy of Marketing Science, 19(3), 209-221. https://doi.org/10.1177/009207039101900306

Greer, T. H., \& Murtaza, M. B. (2003). Web personalization: The impact of perceived innovation characteristics on the intention to use personalization. Journal of Computer Information Systems, 43(3), 50-55. https://doi.org/10.1080/08874417.2003.11647516

Gumussoy, C. A. (2016). Factors affecting users' decision to continue using mobile banking in Turkey. International Journal of Mobile Communications, 14(4), 411-430, https://doi.org/10.1504/IJMC.2016.077341

Gupta, A., \& Arora, N. (2017). Consumer adoption of m-banking: a behavioral reasoning theory perspective. International Journal of Bank Marketing, 35(4), 733-747. https://doi.org/10.1108/IJBM-11-2016-0162

Hair, J. F., Black, W. C., Babin, B. J., Anderson, R. E., \& Tathan, R. L. (2005). Multivariate data analysis. Prentice Hall, Upper.

Hajiyev, J., \& Chang, C. T. (2017). Gen Y members' mobile banking adoption intention and actual use in Azerbaijan and Turkey: The technology acceptance model and social cognitive theory approach. The Journal of Internet Banking and Commerce, 22(1), 1-33.

Hamid, A. A., Razak, F. Z. A., Bakar A. A., \& Abdullah, W. S. W. (2016). The effects of perceived usefulness and perceived ease of use on continuance intention to use e-government, 7th International Economics \& Business Management Conference, Procedia Economics and Finance, 35, 644-649, https://doi.org/10.1016/S2212-5671(16)00079-4

Hanafizadeh, P., Keating, B. W., \& Khedmatgozar, H. R. (2014). A systematic review of internet banking adoption. Telematics and Informatics, 31(3), 492-510. https://doi.org/10.1016/j.tele.2013.04.003

He, P., \& Veronesi, M. (2017). Personality traits and renewable energy technology adoption: A policy case study from China, Energy Policy, 472-479. https://doi.org/10.1016/j.enpol.2017.05.017

Hofstede, G. (1983). The cultural relativity of organizational practices and theories. Journal of International Business Studies, 14(2), 75-89. https://doi.org/10.1057/palgrave.jibs.8490867

Hirschman, E. C. (1980). Innovativeness, novelty seeking, and consumer creativity. Journal of Consumer Research, 7(3), 283-295. https://doi.org/10.1086/208816

Hong, J. C., Lin, P. H., \& Hsieh, P. C. (2017). The effect of consumer innovativeness on perceived value and continuance intention to use smartwatch. Computers in Human Behavior, 67, 264-272. https://doi.org/10.1016/j.chb.2016.11.001

Hubert, M., Florack, A., Gattringer, R., Eberhardt, T., Enkel, E., \& Kenning, P. (2017). Flag up!-Flagship products as important drivers of perceived brand innovativeness. Journal of Business Research, 71, 154-163. https://doi.org/10.1016/j.jbusres.2016.09.001

Im, S., Bayus, B. L., \& Mason, C. H. (2003). An empirical study of innate consumer innovativeness, personal characteristics, and new-product adoption behavior. Journal of the Academy of Marketing Science, 31(1), 61-73. https://doi.org/10.1177/0092070302238602

ING International. (2015). ING International Survey Mobile Banking, New Technologies and Financial Behaviour: The rise of mobile banking and the changing face of payments in the digital age.

Jamal, A., \& Sharifuddin, J. (2015). Perceived value and perceived usefulness of halal labeling: The role of religion and culture. Journal of Business Research, 68, 933-941, https://doi.org/10.1016/j.jbusres.2014.09.020

Jansson, J. (2011). Consumer eco-innovation adoption: assessing attitudinal factors and perceived product characteristics. Business Strategy and the Environment, 20(3), 192-210. https://doi.org/10.1002/bse.690

Kang, Y. M., Cho, C., \& Lee, S. (2011). Analysis of factors affecting the adoption of smartphones. Technology Management Conference (ITMC), 2011 IEEE International (pp. 919-925). IEEE.

Kaplan, M. D. (2009). The relationship between perceived innovativeness and emotional product responses: a brand oriented approach. Innovative Marketing, 5(1), 39-47.

Keller, K. L. (2013). Brand management: Building, measuring, and managing brand equity. Essex, England: 
Pearson.

Koenig-Lewis, N., Palmer, A., \& Moll, A. (2010). Predicting young consumers' take up of mobile banking $\begin{array}{llll}\text { services. International Journal of Bank Marketing, 28(5), 410-432. } & \end{array}$ https://doi.org/10.1108/02652321011064917

Kotler, P., \& Keller, K. (2012). Marketing Management. Essex, England: Pearson.

Krishen, A. S., Berezan, O., Agarwal, S., \& Kachroo, P. (2016). The generation of virtual needs: Recipes for satisfaction in social media networking. Journal of Business Research, 69(11), 5248-5254. https://doi.org/10.1016/j.jbusres.2016.04.120

Lassar, W. M., Manolis, C., \& Lassar, S. S. (2005). The relationship between consumer innovativeness, personal characteristics, and online banking adoption. International Journal of Bank Marketing, 23(2), 176-199. https://doi.org/10.1108/02652320510584403

Laforet, S., \& Li, X. (2005). Consumers' attitudes towards online and mobile banking in China. International Journal of Bank Marketing, 23(5), 362-380. https://doi.org/10.1108/02652320510629250

Li, G., Zhang, R., \& Wang, C. (2015). The role of product originality, usefulness and motivated consumer innovativeness in new product adoption intentions. Journal of Product Innovation Management, 32(2), 214-223. https://doi.org/10.1111/jpim.12169

Lin, H. (2011). An empirical investigation of mobile banking adoption: The effect of innovation attributes and knowledge-based trust. International Journal of Information Management, 31(3), 252-260. https://doi.org/10.1016/j.ijinfomgt.2010.07.006

Makanyeza, C. (2017). Determinants of consumers' intention to adopt mobile banking services in Zimbabwe. International Journal of Bank Marketing, 35(6), 997-1017. https:// doi.org/10.1108/IJBM-07-2016-0099

Mallat, N. (2007). Exploring consumer adoption of mobile payments-A qualitative study. Journal of Strategic Information Systems, 16(4), 413-432. https://doi.org/10.1016/j.jsis.2007.08.001

Midgley, D. F., \& Dowling, G. R. (1978). Innovativeness: The concept and its measurement. Journal of Consumer Research, 4(4), 229-242. https://doi.org/10.1086/208701

Moore, G. C., \& Benbasat, I. (1991). Development of an instrument to measure the perceptions of adopting an information technology innovation. Information System Research, 3(2), 192-222. https://doi.org/10.1287/isre.2.3.192

Pappu, R., \& Quester, P. G. (2016). How does brand innovativeness affect brand loyalty?. European Journal of Marketing, 50(1/2), 2-28. http://dx.doi.org/10.1108/EJM-01-2014-0020

Park, Y., \& Chen, J. V. (2007). Acceptance and adoption of the innovative use of smartphone. Industrial Management \& Data Systems, 107(9), 1349-1365. https://doi.org/10.1108/02635570710834009

Persaud, A., \& Schillo, S. (2014) .Impact of consumer innovativeness, social identity and social networks on purchase decisions. Academy of Management Proceedings, 1. https://doi.org/10.5465/AMBPP.2014.276

Ramdhony, D., \& Munien, S. (2013). An investigation on mobile banking adoption and usage: a case study of Mauritius. World Journal of Social Sciences, 3(3), 197-217.

Rejikumar, G., \& Sudharani Ravindran, R. (2012). An empirical study on service quality perceptions and continuance intention in mobile banking context in India. Journal of Internet Banking and Commerce, 17(1), $1-22$.

Rogers, E. M. (1976). New Product Adoption and diffusion. The Journal of Consumer Research, 2, 290-301. https://doi.org/10.1086/208642

Rogers, E. M. (1995). Lessons for guidelines from the diffusion of innovations. The Joint Commission Journal on Quality Improvement, 21(7), 324-328. http://dx.doi.org/10.1016/S1070-3241(16)30155-9

Rogers, E. M. (2003). Diffusion of innovations (5th edition). New York: Free Press.

Rodrigues L. F., Oliveira A., \& Costa C. J. (2016). Does ease-of-use contributes to the perception of enjoyment? A case of gamification in e-banking. Computers in Human Behavior, 61, 114-126, https://doi.org/10.1016/j.chb.2016.03.015

Rubera, G., \& Kirca, A. H. (2017). You gotta serve somebody: the effects of firm innovation on customer satisfaction and firm value. Journal of the Academy of Marketing Science, 1-21, 
http://dx.doi.org/10.1007/s11747-016-0512-7

Sanayei, A., Shahin, A., \& Taherfar, A. (2013). Analyzing the effects of brand innovativeness on attitudes towards the brand considering the moderating role of consumer innovativeness with a case study in students of university of Isfahan. International Journal of Academic Research in Accounting, Finance and Management Sciences, 3(3), 290-297. https://doi.org/10.6007/IJARAFMS/v3-i3/187

Shams, R., Alpert, F., \& Brown, M. (2015). Consumer perceived brand innovativeness: conceptualization and operationalization. European Journal of Marketing, 49(9/10), 1589-1615. http://dx.doi.org/10.1108/EJM-05-2013-0240

Sharma, S. K., Govindaluri, S. M., Al-Muharrami, S., \& Tarhini, A. (2017). A multi-analytical model for mobile banking adoption: A developing country perspective. Review of International Business and Strategy, 27(1), 133-148. https://doi.org/10.1108/RIBS-11-2016-0074

Sohail, M. S., \& Shanmugham, B. (2003). E-banking and customer preferences in Malaysia: An empirical investigation. Information Sciences, 150(3), 207-217. https://doi.org/10.1016/S0020-0255(02)00378-X

Solomon, M., Bamossy, G., Askegaard, S., \& Hogg, M. (2006). Consumer behaviour: A European perspective. Essex, England: Pearson.

Szopiński, T. S. (2016). Factors affecting the adoption of online banking in Poland. Journal of Business Research, 69(11), 4763-4768. http://dx.doi.org/10.1016/j.jbusres.2016.04.027

Tan, M., \& Teo, T. S. (2000). Factors influencing the adoption of Internet banking. Journal of the AIS, 1 (1es), 5.

Tornatzky, L. G., \& Klein, K. J. (1982). Innovation characteristics and innovation adoption-implementation: A meta-analysis of findings. IEEE Transactions on Engineering Management, 1, 28-45,

Truong, Y. (2013). A cross-country study of consumer innovativeness and technological service innovation. $\begin{array}{lllll}\text { Journal of Retailing and Consumer } & \text { Services, 20(1), 130-137. }\end{array}$ http://dx.doi.org/10.1016/j.jretconser.2012.10.014

Wang, G., Dou, W., \& Zhou, N. (2008). Consumption attitudes and adoption of new consumer products: a contingency approach. European Journal of Marketing, 42(1/2), 238-254. https://doi.org/10.1108/03090560810840998

Wang, C., Lee, M. K., \& Hua, Z. (2015). A theory of social media dependence: Evidence from microblog users. Decision Support Systems, 69, 40-49. https://doi.org/10.1016/j.dss.2014.11.002

Wu, J. H., \& Wang, S. C. (2005). What drives mobile commerce? An empirical evaluation of the revised technology acceptance model. Information and Management, 42(5), 719-729. https://doi.org/10.1016/j.im.2004.07.001

Zhou, T. (2012). Examining mobile banking user adoption from the perspectives of trust and flow experience. Information Technology and Management, 13(1), 27-37. https://doi.org/10.1007/s10799-011-0111-8

\section{Copyrights}

Copyright for this article is retained by the author, with first publication rights granted to the journal.

This is an open-access article distributed under the terms and conditions of the Creative Commons Attribution license (http://creativecommons.org/licenses/by/4.0/). 